\title{
Diversity of wild edible plants traditionally used by the Galo tribe of Indian Eastern Himalayan state of Arunachal Pradesh
}

\author{
Tajum Doni \& Padma Raj Gajurel ${ }^{*}$ \\ Forest Systematic \& Ethnobiology Laboratory, Department of Forestry, North Eastern Regional Institute of Science and Technology, \\ Nirjuli 791 109, Arunachal Pradesh, India \\ *Email: prgajurel@gmail.com
}

\section{ARTICLE HISTORY}

Received: 02 July 2020

Accepted: 10 August 2020

Published: 01 October 2020

\section{KEYWORDS}

Galo tribe

Ethnobotany

Wild edible plants

Edibility index

Relative frequency citation

Harvesting frequency

\section{ABSTRACT}

Wild edible plants are found very useful in the fulfilment of food and nutritional requirements. Because of the availability and cultural preference, the consumption of these plants among the tribes is high. To find out the diversity, utilisation pattern and sociocultural importance of the wild plants, a study was conducted in the state of Arunachal Pradesh selecting the Galo tribe, and accordingly the wild edible plants consumed are documented here. Data were collected through extensive field surveys and interviews with the community in the selected 12 villages in Upper Subansiri and West Siang districts of Arunachal Pradesh. Overall, 125 wild edible plant species under 99 genera and 54 families are reported. These species are consumed mostly as leafy vegetables, fruits, medicine, spices and condiments and as a substitute to food grains. The Urticaceae with ten species is the most utilised family followed by Asteraceae, Moraceae and Lamiaceae with at least five species in each. Herbs with 47 species were found to be the most dominant growth form followed by trees with 44 species. Based on parts used leaves with 66 species were recorded to be the most used plant parts followed by fruits. The highest edibility index of $50 \%$ was reported in Solanum americanum. The analysis of relative frequency of citation revealed that total 78 species exhibits more than 0.50 relative frequency of citation value with highest value in Pouzolzia hirta (0.95). It has been found that the wild plant resources play a vital role in the socio-economic aspects of the Galo tribe.

\section{Introduction}

Wild edible plants are the non-cultivated plant species available in their natural habitat and are being used as a source of nutrition, food, medicine and various other purposes by the majority of indigenous and rural communities across the world (1). Out of about 422000 recorded plant taxa globally, nearly 20000 species are reported to be wild edible and more than $85 \%$ of world population depends on less than 20 plant taxa for their daily caloric need (2). In Indian subcontinent alone, about 9500 wild plant are utilised for food, medicine and other purposes of by 553 different tribal communities (3). Tribal and rural communities have acquired a unique knowledge, about the use of wild edible plants, through age-old experiences, which are being transferred orally from one generation to another. Traditional knowledge regarding the uses of wild edible plants, their numbers and frequencies of use vary with tradition, culture and location and are restricted within certain communities. However, the knowledge on the uses of wild edible plants is diminishing due to large-scale migration of population towards urban areas, a rapid decline of natural resources and changing cultural tradition (4-6).

Wild edible plants play a significant role in complementing the global food basket specially in rural areas. The use of wild plant resources has been an integral part of cultural, religious and health aspect of numerous indigenous and rural communities across the globe. Assuming the importance, the documentation of ethnobotanical and traditional knowledge of various communities for identification of potential wild edible plants have been undertaken worldwide (7-12). These studies highlighted the selection of promising species for domestication for

(c) Doni \& Gajurel (2020). This is an open-access article distributed under the terms of the Creative Commons Attribution License, which permits unrestricted use, distribution and reproduction in any medium, provided the original author and source are credited (https://creativecommons.org/licenses/by/4.0/).

To cite this article: Doni T, Gajurel P R Diversity of wild edible plants traditionally used by the Galo tribe of Indian Eastern Himalayan state of Arunachal Pradesh Plant Science Today. 2020;7(4):523-533. https://doi.org/10.14719/pst.2020.7.4.855 
dietary alternatives and to meet the nutritional requirement of the large population. India is known for its rich floristic and cultural diversity where a large number of plant species are consumed by the rural communities, forming an integral part of the food and dietary requirements (13-16).

Arunachal Pradesh, situated in the eastern Himalaya covering a total geographical area of 83743 $\mathrm{km}^{2}$, is the largest state in North East India. The state lies between $26^{\circ} 28^{\prime}-29^{\circ} 30^{\prime} \mathrm{N}$ Latitude and 91 $30^{\prime}-$ $97^{\circ} 30^{\prime} \mathrm{E}$ Longitude and is situated in the transition zone of the Himalayan and Indo-Burma mega biodiversity hotspots. Owing to varied physiographic, climatic and ecological variations, the state is endowed with rich floral and faunal diversity and is regarded as a paradise of ethnobotanical studies (17). It is also found as the hub of wild food and medicinal plants. Culturally the state is home to 26 major and 110 minor tribes, making it one of the largest abodes of varied ethnic tribal groups (18). The Galo is one of the major tribe of Abo-Tani descendant (Abo-Tani means the great ancestor of humankind) belong to Palae-mongoloid stock primarily inhabiting in the Upper Subansiri and West Siang districts in the central part of the state (19). The tribe is being hailed for their innovativeness and hardworking nature, and are considered to be one of the prosperous and culturally vibrant tribes of the Eastern Himalaya (20). Agriculture is the main occupation and jhum cultivation is still the predominant way of cultivation. Galo tribe still follow the age-old culture and tradition and utilise wild forest resources for various purposes such as food, nutritional and medicinal requirement. Besides, the wild edibles also play a vital role in revenue generation as they are being sold regularly in the local markets.

Although some studies have been carried on documentation of various plants used by the Galo tribe (21-24), a comprehensive account is not available. In this perspective, the present study was undertaken with the aim of documenting the wild edible plants including the taxonomic diversity, detailed utilisation pattern and identification of culturally and economically potential species. The two major hypotheses of the study are - rich diversity of wild edible forest resources and their crucial role in the livelihood of the local communities.

\section{Materials and Methods}

\section{Study area}

The present study was carried out in Upper Subansiri and West Siang districts of Arunachal Pradesh (Fig. 1). The areas lie in the central region of the state within a geographical tract of $28^{\circ} 5^{\prime}-28^{\circ} 25^{\prime}$ latitudes

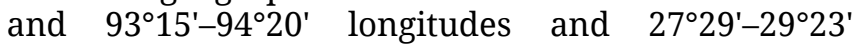
latitudes and $94^{\circ} 02^{\prime}-95^{\circ} 15^{\prime}$ respectively, covering a combined total geographical area of $15357 \mathrm{~km}^{2}(18.34$ $\%)$ of the state (25). The topography of both the districts is marked by the rugged and hilly terrain with the high mountain which generally remains cold almost throughout the year and the plain areas in foothills are intersected by two major rivers viz., Subansiri and Yomgo and nuemerous streams. The continental climate type of both the districts is marked with an average rainfall of $3000 \mathrm{~mm}$ and temperature ranges from $5{ }^{\circ} \mathrm{C}$ in winter to $38{ }^{\circ} \mathrm{C}$ in summer in foothill plain areas whereas, from below freezing point to $25{ }^{\circ} \mathrm{C}$ in higher reaches (26). Although the study area mostly harbour tropical and subtropical forests with rich floral and faunal diversity, the temperate and sub-alpine forests are also prevalent.

\section{Methodology}

An ethnobotanical survey using standard method (27, 28) was carried out in 12 selected villages of Upper Subansiri and West Siang districts (Fig. 1) covering a total of 6 administrative circles (3 administrative circles from each district) during 2017-2019. Before carrying out the ethnobotanical survey and data collection, the head of the concerned villages were informed. As the first author is from the Galo tribe and also from the study area, it became easier for data collection, as it helped in understanding the local dialogue and terminologies. Regular field visits were made for the collection of data covering different seasons.

A total of 120 informants were considered for interviewing and data collection. Ten informants from each villages covering different age groups and sex were selected purposively and targeted for questioning and discussion. The informants mostly comprised the village head, elderly people, man and women folks associated with food plant collection and with traditional knowledge about their uses. Data were collected using a pre-structured questionnaire having all the probable parameters to incorporate the needful data on seasonal availability of edible plants, their parts used, local names, utilisation pattern, preference, harvesting methods etc. Regular visits to forest areas were made for the collection of voucher specimens for herbarium preparation (29). The plant species were identified with the help of taxonomic experts, relevant taxonomic literature (30-31) and in consultation with the specimens available at the regional Herbaria (ARUN and ASSAM) of the Botanical Survey of India and Herbarium of the State Forest Research Institute (APSH), Itanagar. The voucher specimens were deposited at Forestry Herbarium, Department of Forestry, NERIST. The market survey of four major local markets, two from each districts was also carried out to assess the available wild edible plants being marketed following standard methodology (32).

\section{Quantative analysis}

In order to gain understanding and identification of the commonly preferred and valuable species of the wild edible plants and their local importance, the following quantitative analysis were also attempted.

Edibility Index (EI): EI of all the wild edible plant species was worked out using a component-wise scale value method (33). The value of scale ranges from one to ten and each plant component (leaf, seed, flower, stem, bark, root, resin, gum, entire aerial part and whole plant) was assigned a value of $10 \%$ each. EI was calculated by dividing the summing up component usage of each edible plant with the whole 

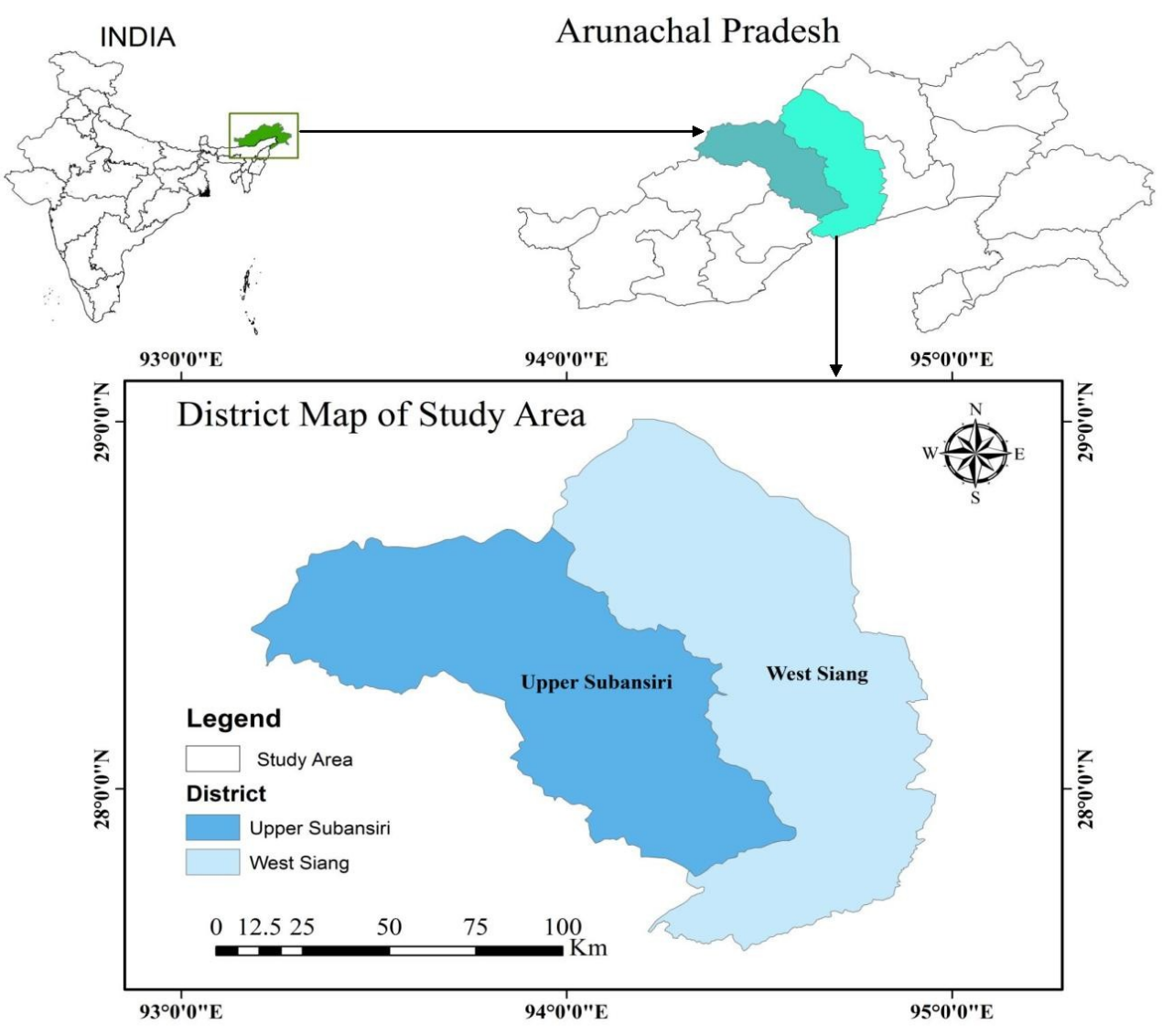

Fig. 1. Map showing the study area.

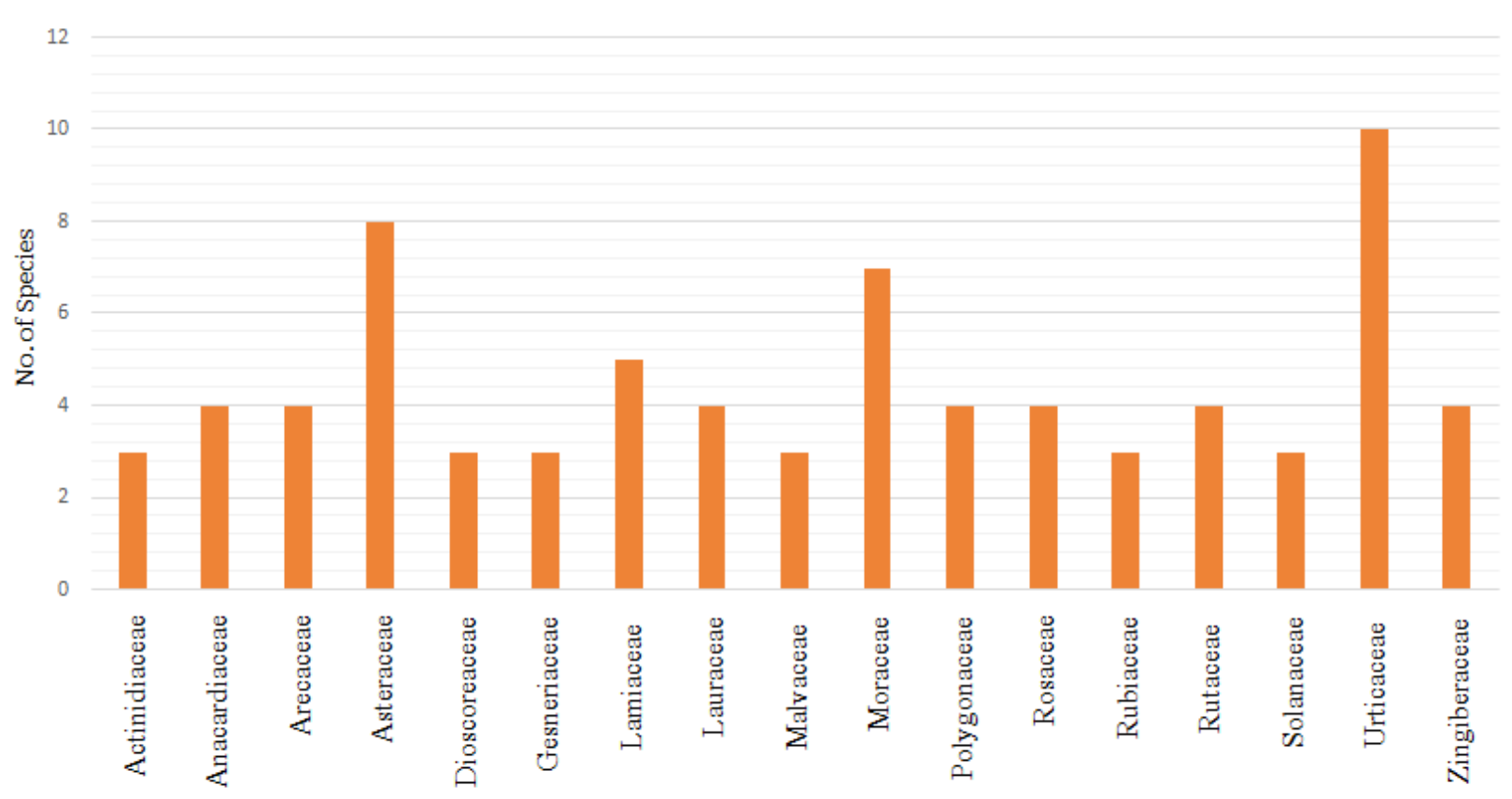

No. of Families

Fig. 2. Dominant families of wild edible plant species used by Galo tribe.

plant (WP) score of $100 \%$. The following formula was used for calculating EI:

$$
E I(\%)=\frac{P U i}{W P U i} \times 100
$$

Where, EI = Edibility index, $P U i=$ parts used of $i$ th species, $W P U i=$ whole plant use of $i$ th species.

\section{Relative Frequency of Citation (RFC):}

The RFC value of each species were calculated following the standard methods (34). The RFC value 
ranges from 0 (none of informant mentioned the use of plant) to 1 (use of plant is mentioned by all the informants) and was worked out using the formula:

$\mathrm{RFC}=\mathrm{FCs} / \mathrm{N}$,

where FCs= number of informants mentioned the use of species and $\mathrm{N}=$ Total number of informants of the study i.e 120 in the present study.

\section{Results}

\section{Wild edible plants diversity}

The results of the present ethnobotanical study indicated that the Galo tribe of the Indian state of Arunachal Pradesh uses a large number of wild edible plant species as per their culture and tradition. A total of 125 wild edible plant species belonging to 99 genera and 54 families have been reported to be used by the tribe to meet the food and nutritional requirements. Except, one species of Gymnosperm and four species of Pteridophytes, the rest of the species belongs to Angiosperms representing 44 dicotyledonous and 7 monocotyledonous families. Among the families recorded, Urticaceae with ten species was recorded to be the most dominant family commonly used as wild edible by the tribe. Other dominant families were, Asteraceae (8 spp.), Moraceae (7 spp.) and Lamiaceae (5 spp.) (Fig. 2). Genera wise Ficus was found to be the most dominant genera with five species followed by Dioscorea, Rubus and Saurauia each with three species. Based on the major life forms, the maximum number of plant species recorded were herbs with 47 spp (38\%), followed by trees having 44 spp (35\%), shrubs 24 spp (19\%), and climbers $10 \mathrm{spp}$ (8\%) (Fig. 3 ). The details of all the species recorded are listed in Supplementary Table 1 incorporating the botanical name, family vernacular name, voucher number, habit, parts used, categories of uses etc.

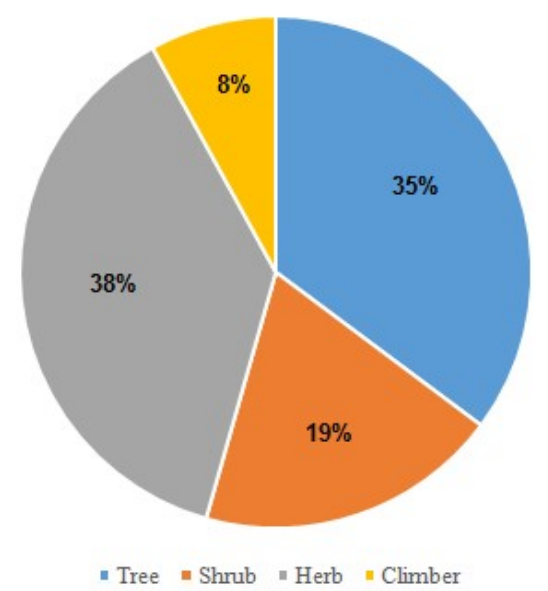

Fig. 3. Habit wise diversity of wild edible plant species used by Galo tribe.

When all the edible plants used by the Galo tribe were categorised based on their uses, they are classified into five distinct groups viz. vegetables, edible fruits, spices and condiments, alternative foods (substitutes for food grain) and mouth fresheners (Fig. 4). Among these categories, the maximum number of species are used as vegetables (66 spp.), followed by edible fruits (51 spp.), spices and condiments (10 spp.), mouth fresheners (3 spp.) and two species as alternative foods. Although almost all the plant parts were found useful, the leaves or leafy shoots consumed for vegetables represent the maximum number with 64 species $(26 \%)$ followed by the edible fruits taken either as a raw or dried form with 50 species (25\%). A good number of flowers and seeds of different plant species were also recorded to be edible. Roots and tubers were least in numbers among the reported as edible. The majority of the recorded edible fruits are consumed raw; however, the leaves, flowers, stems, roots and tubers which are mainly used as vegetables are cooked for consumption. The vegetables are mostly cooked in the form of boiled food with salt, garlic and chilly as major ingredients. However, the leaves of Centella asiatica, Houttuynia cordata, Hydrocotyle javanica, Oxalis debilis var. corymbosa and stem of Begonia aborensis were usually consumed as raw. Seeds of edible fruits such as Artocarpus heterophyllus, Castanopsis hystrix, $C$. indica are usually roasted for consumption (Supplementary Table 1 \& Fig. 5). Among the reported wild edibles, 20 species were also used medicinally for curing various health ailments.

\section{Harvesting frequency and marketing potential of wild edible plants}

Based on the information gathered during the questionnaire survey and group discussions with the villagers, it was found that about 46 species were highly preferred and harvested frequently by the community to meet their daily nutritional needs (Table 1). These species were also found supportive in revenue generation through trading in the local markets. The frequently harvested species includes the most commonly used wild edible vegetables such as Clerodendrum glandulosum, Pouzolzia hirta, Gynura bicolor, Houttuynia cordata, Litsea cubeba, Piper pedicellatum, Solanum americanum, Spilanthes acmella, Zanthoxylum rhetsa etc. The majority of the species harvested frequently represent the leafy vegetables. As the leaves are the only parts available throughout the growing season, they are collected year round based on availability and by virtue, their consumption becomes higher. On the other hand, 28 species are were found moderately harvested while 50 species are harvested rarely.

The market survey of the study area revealed that apart from meeting their daily household needs, the local community also used to collect wild edible plant for a supplementary source of income. A total of 41 species were found to be sold in the local markets for subsidising income and economic benefits. Among these, species like Acmella paniculata, Allium hookeri, Amomum dealbatum, Clerodendrum glandulosum, Dioscorea bulbifera, Diplazium esculentum, Elatostema platyphyllum, Pouzolzia hirta, Gynura bicolor, Houttuynia cordata, Impatiens vadyae, Litsea cubeba, Musa balbisiana, Phoebe cooperiana, Phyllostachys bambusoides, Pilea pumila, Piper pedicellatum, Solanum americanum, Spilanthes acmella, Zanthoxylum rhetsa were found to be highly preferred wild edible plants among the local consumers and hence showed good market 
Table 1. Highly preferred wild edible plants by Galo tribe.

\begin{tabular}{|c|c|c|c|c|}
\hline Sl. No & Botanical name & Part harvested & Purpose of harvest & Season of harvest \\
\hline 1. & Acmella paniculata & Leaf & Household \& economic & All season \\
\hline 2. & Allium hookeri & Whole part & Household \& economic & December - February \\
\hline 3. & Amaranthus viridis & Leaf & Household \& economic & All season \\
\hline 4. & Amomum dealbatum & Fruit & Economic & September - November \\
\hline 5. & Artocarpus heterophyllus & Fruit & Household \& economic & April-June \\
\hline 6. & Cardamine hirsuta & Leaf & Household \& economic & All season \\
\hline 7. & Castanopsis hystrix & Fruit & Economic & June - August \\
\hline 8. & Castanopsis indica & Fruit & Economic & October - December \\
\hline 9. & Centella asiatica & Whole part & Economic & All season \\
\hline 10. & Chenopodium album & Leaf & Household \& economic & June - September \\
\hline 11. & Cinnamomum tamala & Leaf & Economic & All season \\
\hline 12. & Clerodendrum glandulosum & Leaf & Household \& economic & All season \\
\hline 13. & Corchorus capsularis & Leaf & Household & All season \\
\hline 14. & Crassocephalum crepidioides & Leaf & Household & All season \\
\hline 15. & Dillenia indica & Fruit & Economic & September - November \\
\hline 16. & Dioscorea esculentum & Tuber & Economic & November - January \\
\hline 17. & Dioscorea bulbifera & Tuber & Economic & October - December \\
\hline 18. & Diplazium esculentum & Leaf & Household & All season \\
\hline 19. & Elatostema platyphyllum & Leaf & Economic & September - November \\
\hline 20. & Eryngium foetidum & Leaf & Economic & All season \\
\hline 21. & Fagopyrum esculentum & Leaf & Household & All season \\
\hline 22. & Ficus auriculata & Fruit & Household & April - June \\
\hline 23. & Ficus racemosa & Leaf & Household & All season \\
\hline 24. & Garcinia indica & Fruit & Household \& economic & May - July \\
\hline 25. & Gynura bicolor & Leaf & Household \& economic & All season \\
\hline 26. & Henckelia adenocalyx & Leaf & Household & All season \\
\hline 27. & Hornstedtia arunachalensis & Fruit & Household & September - November \\
\hline 28. & Houttuynia cordata & Leaf, root & Household \& economic & All season \\
\hline 29. & Impatiens vadyae & Leaf & Economic & All season \\
\hline 30. & Litsea cubeba & Young fruit & Household \& economic & April-June \\
\hline 31. & Mangifera sylvatica & Fruit & Household & November - January \\
\hline 32. & Musa balbisiana & Inflorescence & Economic & All season \\
\hline 33. & Mussaenda roxburghii & Leaf & Household & All season \\
\hline 34. & Phoebe cooperiana & Young fruit & Economic & August - October \\
\hline 35. & Phyllostachys bambusoides & Young shoot & Economic & February - April \\
\hline 36. & Pilea pumila & Leaf & Economic & All season \\
\hline 37. & Piper pedicellatum & Leaf & Household \& economic & All season \\
\hline 38. & Pouzolzia hirta & Leaf & Household \& economic & All season \\
\hline 39. & Pouzolzia sanguinea & Leaf & Household & All season \\
\hline 40. & Rhynchotechum ellipticum & Leaf & Household \& economic & All season \\
\hline 41. & Rubus rosifolius & Fruit & Household & April - June \\
\hline 42. & Selaginella wallichii & Leaf & Economic & All season \\
\hline 43. & Solanum americanum & Leaf & Household \& economic & All season \\
\hline 44. & Spilanthes acmella & Leaf & Household \& economic & All season \\
\hline 45. & Zanthoxylum armatum & Fruit & Economic & May - July \\
\hline 46. & Zanthoxylum rhetsa & Leaf & Household \& economic & All season \\
\hline
\end{tabular}

demand. The parts of these species were sold in higher rate among all the marketed species which cost a minimum of Rs $80 / \mathrm{Kg}$. In the market these items are normally sold in the form of a bunch, group or bundle as per the plant parts @ Rs. 20 to Rs. 40 per unit. Besides, the species like Amaranthus viridis, Artocarpus heterophyllus, Averrhoa carambola, Castanopsis hystrix, C. indica, Centella asiatica, Chenopodium album, Cinnamomum tamala, Corchorus capsularis, Crassocephalum crepidioides, Dillenia indica, Dioscorea alata, Elaeocarpus floribundus, Eryngium foetidum, Fagopyrum esculentum, Garcinia indica, Gynura cusimbua, Hydrocotyle javanica, Mentha spicata, Piper longum, Zanthoxylum armatum were also found to have market potential. Among the most preferred ones, the species like Dioscorea bulbifera, Impatiens vadyae, Litsea cubeba, Phoebe cooperiana, Phyllostachys bambusoides etc. marketed seasonally. While, the species that are consumed for their leaves or leafy shoots were marketed throughout the year. These include Acmella paniculata, Clerodendrum glandulosum, Crassocephalum crepidioides, Dioscorea esculenta, Elatostema platyphyllum, Pouzolzia. hirta, Houttuynia cordata, Piper pedicellatum, Solanum nigrum, Spilanthes acmella and Zanthoxyllum rhetsa. Some of the wild plant species used as vegetables and fruits by the Galos are shown in Fig. 6 \& 7 .

\section{Quantitative analysis}

\section{Edibility index of wild edible plants:}

Component wise usage assessment of wild edible plants reveals the usability of particular plants parts and their current status of consumption of a particular plant species by the Galo tribe. The analysis showed that 29 species have at least $30 \%$ or more edibility index (Supplementary Table 1). The highest edibility index was recorded in Solanum americanum with $50 \%$, while three species, Chenopodium album, Houttuynia cordata and Oxalis debilis var. corymbosa showed edibility index of $40 \%$ each. On the other hand, 56 species show an edibility index of $20 \%$ and the lowest edibility index of $10 \%$ was recorded in 40 species.

\section{Relative frequency of citation (RFC):}

RFC revealed the importance of wild edible species with respect to local informants who cited the plant. 


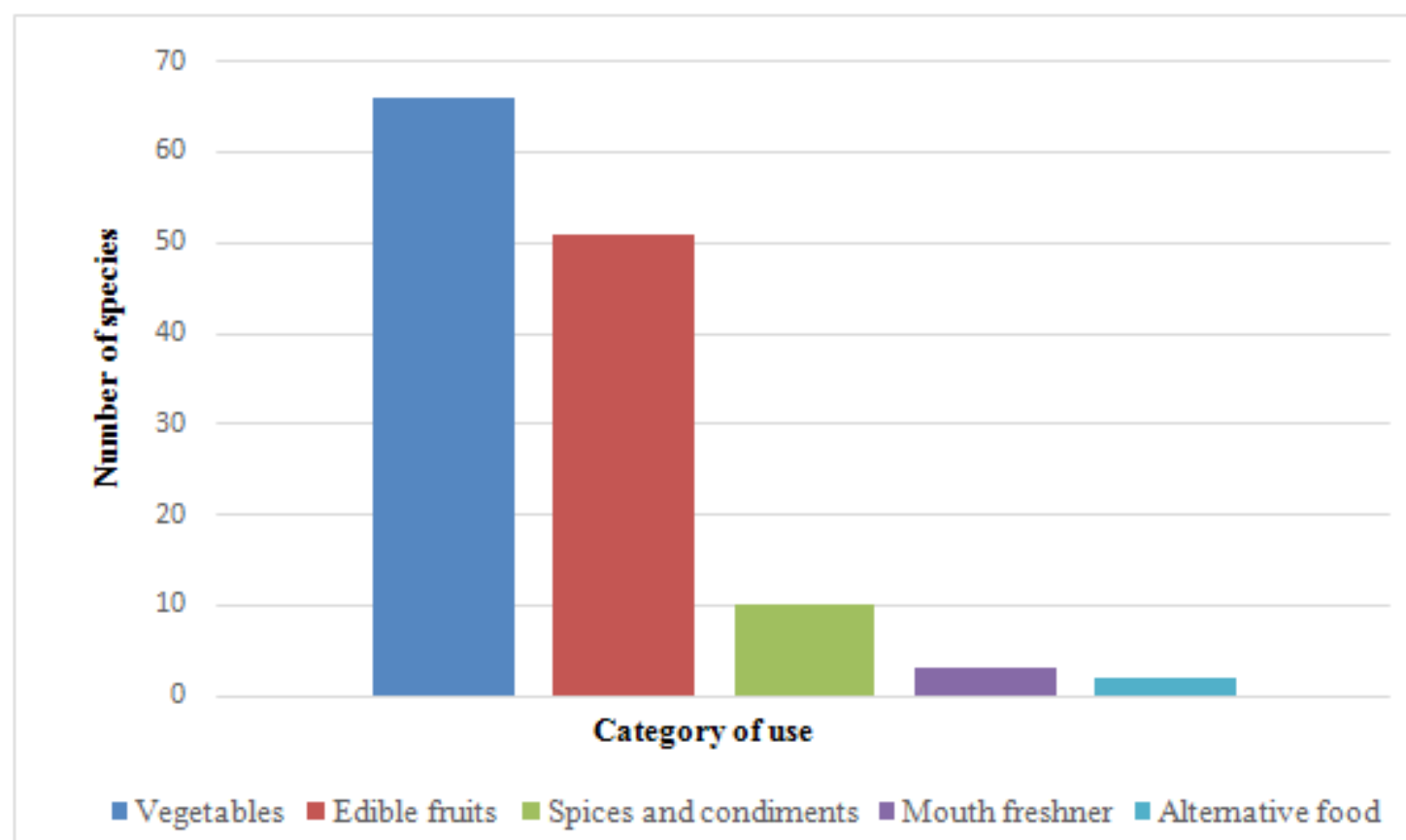

Fig. 4. Category wise uses of wild edible plant species used by Galo tribe.

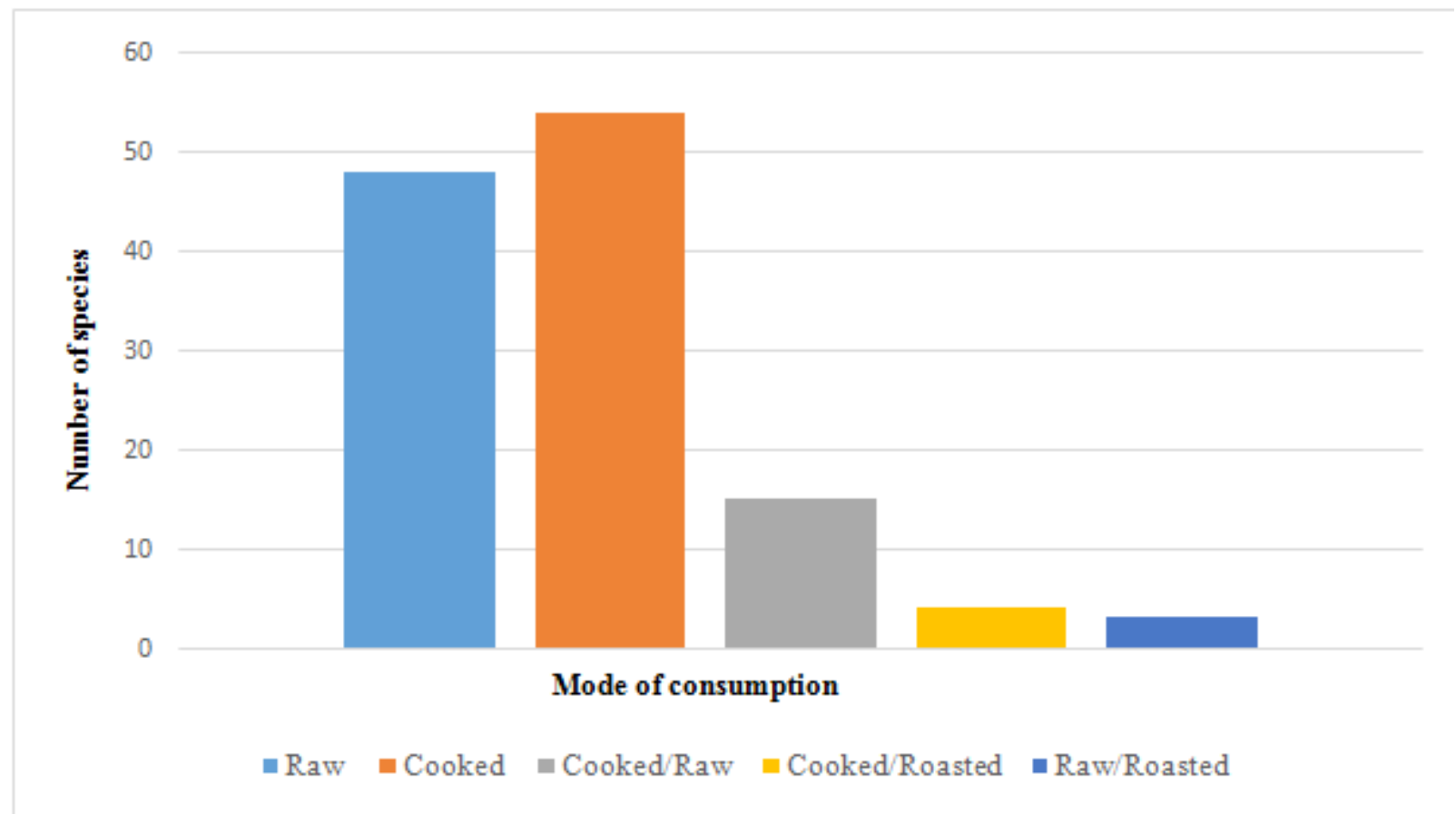

Fig. 5. Mode of consumption of wild edible plants by Galo tribe.

RFC value of the present study ranges from 0.24 to 0.95 (Supplementary Table 1). The maximum value of RFC were recorded in Pouzolzia hirta (0.95), Piper pedicellatum (0.94), Zanthoxylum rhetsa (0.92) and Clerodendrum glandulosum (0.90). Whereas, lowest value were recorded in Erigeron canadensis (0.24), Baliospermum calycinum and Osbeckia nutans with RFC value of 0.25 each.

\section{Discussion}

Globally wild edible plants are preferred and collected to fulfil the food and nutritional requirements by the rural communities. In rural India, the uses of the wild edible as food stuffs is a common practice and report on consumption of more than 1400 species under 184 families by the different communities have already been depicted (16). The present ethnobotanical study on Galo tribes in the Indian Eastern Himalayan state of Arunachal Pradesh also revealed the uses of a large number species as wild edibles. The study confirmed the uses of 125 plant species that are being used for various purposes in the form of wild edible. The results of the present study are although in conformity with the reports of previous studies, on different tribes of 
north eastern region $(13,35,36,37)$ as well as other Indian states $(3,14,15)$, the number of species reported here is comparatively higher. Uses of about 195 plant species as wild edible by the tribal communities from Indian Himalayan region have harbour a rich diversity of various useful wild plants, and the tribal communities of the region including the Galo tribes of Arunachal Pradesh have vast traditional knowledge associated with selection and utilisation of different plants. Although the

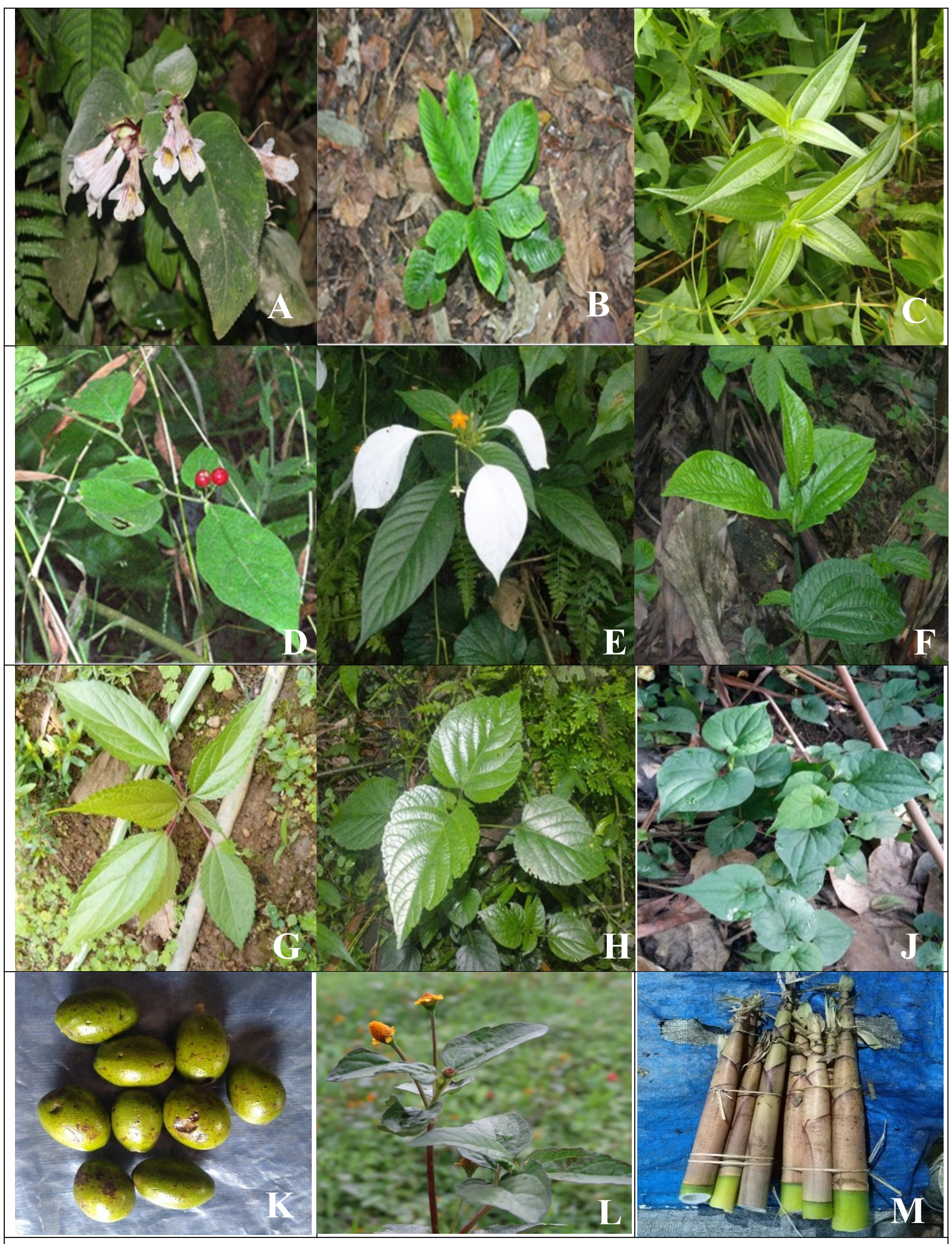

Fig. 6. Wild vegetable plants used by Galo tribe A. Henckelia adenocalyx B. Rhynchotechum ellipticum C. Pouzolzia hirta D. Lycianthes laevis E. Mussaenda roxburghii F. Piper pedicellatum G. Pouzolzia sanguinea H. Clerodendrum glandulosum J. Houttuynia cordata K. Phoebe cooperiana L. Spilanthes acmella M. Phyllostachys bambusoides.

also been reported in the previous studies (32). The results justifies that the forest areas of the region consumption of some of the wild plants by Galo tribes reported here were highlighted previously (21-22), 

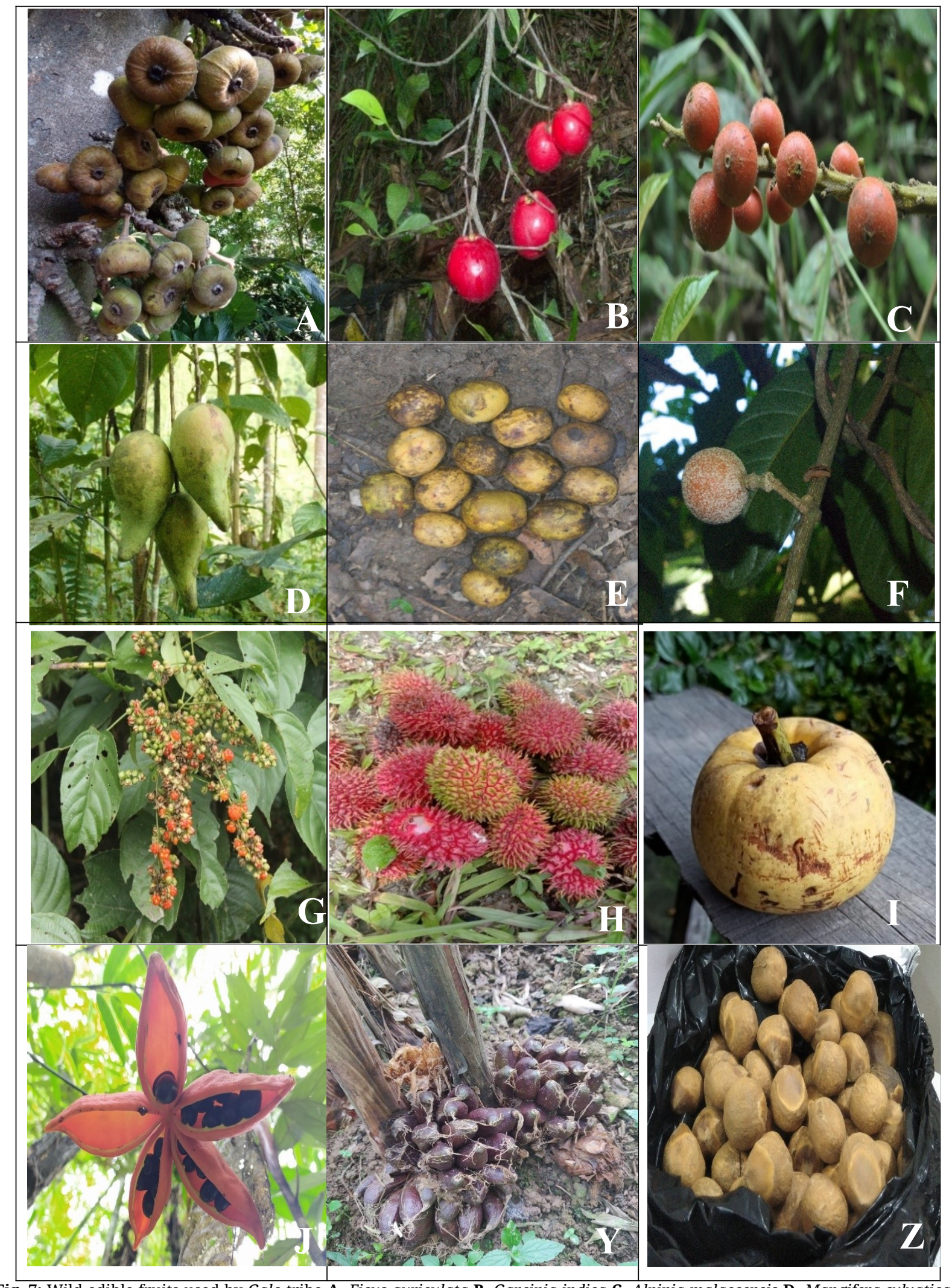

Fig. 7: Wild edible fruits used by Galo tribe A. Ficus auriculata B. Garcinia indica C. Alpinia malaccensis D. Mangifera sylvatica E. Choerospondias axillaris F. Stixis suaveolens G. Rubus lucens H. Nephelium lappaceum I. Garcinia pedunculata J. Sterculia lanceolata K. Amomum dealbatum L. Castanopsis hystrix.

the present study added 71 additional species to the list of wild edible plants of the Galo tribe. Hence, the present study forms a comprehensive account of the wild plants of the Galo tribe. It also reflects the vast traditional knowledge and preference and dependency of the Galos on wild edible plants to meet their food and nutritional requirements.
Dependency on wild plants for day to day activities and consumption of many wild plants for various dietry requirements by the tribes of north eastern region have already been highlighted in different studies $(32,37,38)$.

The edible use of the four species namely Henckelia adenocalyx, Hornstedtia arunachalensis, 
Impatiens vadyae, Meliosma rhoifolia var. barbulata, reported in the present work have not been known earlier and hence probably forms the first report. It suggests that there is still huge hidden traditional knowledge in unexplored areas which may be inspiring for the ethnobiological researchers to carry out studies in those areas. The present report provides scope for further study of the aforesaid species from the nutritional and phytochemical aspects which, if found suitable, may contribute substantially to the nutraceutical industries.

The majority of leafy vegetable and fruits are consumed in fresh form through seasonal preference and selection. Thus, it can be stated that the consumption of wild edible plants is a common livelihood option of the Galos to fulfil the food and nutritional requirements for all the age groups from the children to the elderly people. The high usage of wild edible plants indicates availability and ease of accessibility of various wild resources coupled with vast associated traditional knowledge on its utility. This indicates the huge gene pool diversity of wild edible plants in the region, which further provides scope for suitable agro-horticultural research interventions for improving economic and livelihood security of the tribal communities of the region.

The complete nutritional analysis and data of the wild plants used may pave way for the selection of nutritionally important plant resources, which in the long run may contribute substantially toward fulfilling FAO and World Health Organisation's target of eradicating all forms of malnutrition (39). The potential contribution of wild edible plants towards meeting the daily nutritional requirement of the rural population has also been highlighted previously by various workers (40-41).

The study reveals that 46 species are being frequently harvested by the local people to meet their daily household requirements, out of which 41 species have market value and are sold in the local market. These species are playing a vital role in the livelihood improvement of the Galos by providing supplementary income. However, due to the ease of accessibility and availability of the species in the wild and lack of standardised cultivation and harvesting practices, the local people still collect a large quantity of the wild edible plants from the natural habitats for both household need and economic earning. The unsustainable methods of collection of some important wild edible plants, such as the collection of huge quantities of immature fruits of, Litsea cubeba, Phoebe cooperiana, Zanthoxylum armatum, Zanthoxylum rhetsa etc. without allowing it to replenish naturally may result in a decrease in population in its natural habitats. Thus, there is need to create awareness among local communities on the sustainable harvesting methods and standardized cultivation practices of economically important wild edible plants, to meet the future household and socioeconomic need and to reduce pressure on wild population. Inclusion of wild edible plants in the traditional home garden and other agroforestry practices may also be another option in supplementing the household and market demand. It has also been noted that 20 species are also being used by the tribe to cure various health ailments, thus recognising both the medicinal and nutritional values. The uses of wild edible plants as medicine for their therapeutic properties have also been highlighted by other workers $(10,42,43)$. It increases the importance of the wild edibles in the livelihood aspects of different various communities and potentiality of such resources in health management practices.

The component wise assessment reflects the consumptive sense of tribe regarding particular parts of wild edible plants. Except for four species, all the species showed less than $30 \%$ edibility index reflecting the preference of the tribe in consuming the different parts of a particular species. The result of the present study was found to be very contrasting with the findings from Himachal Pradesh (33), the western Himalayan state of India, where, edibility index of $100 \%$ was reported for 2 species and more than $80 \%$ for 11 species. Overall, more than $36 \%$ of the total 85 species reported by them have a higher edibility index. The differences in the edibility level of a particular species may be attributed to the restricted knowledge of specific tribe in the selection of wild edible plant species (44) which augments further scope for exploration of different plant parts of a species having low edibility index for its consumptive possibilities.

The analysis of relative frequency citation (RFC) of species revealed that above $60 \%$ species are preferred by more than $50 \%$ informants showing higher RFC values. Maximum value of RFC were reported in the species like Pouzolzia hirta, Piper pedicellatum, Zanthoxylum rhetsa, Clerodendrum glandulosum etc which are also found as preferred vegetable plants of the state $(18,22,45)$. The report of higher value in these species indicates cultural and traditional importance of species among the local communities $(10,46)$. In a study it was reported that the RFC value ranges from 0.38 to 0.70 , with the highest value in Cannabis sativa and concluded that, the vast distribution, ease of availability and frequent consumption of particular plants by the local communities as the reason for higher RFC (46). However, medicinal and economic attributes of edible plant resources may also be determinant factor in higher RFC, as most of the species with higher RFC value in the present study are being used by the local communities for medicinal purpose as well as to generate supplementary income.

\section{Conclusion}

The wild plant resources play a vital role in the livelihood improvement of the poor tribal communities having limitations of other livelihood options due to inadequate infrastructural facilities in the Himalayan terrain. The gathering of the various plant parts and their marketing have been adopted as one of the best livelihood options as many of the species showed higher market potentiality. The present study also noted that the recent trends of population migration from rural to urban areas. Changing lifestyles of the local communities due to urbanisation have resulted in less reliance on 
traditional livelihood practices. There is a rapid decline in the traditional and oral transfer of traditional knowledge in both urban and rural areas. Therefore, it becomes imperative to document and preserve the rich traditional knowledge to serve future generations as well as for conservation and harnessing of useful wild species for prospects.

\section{Acknowledgements}

The authors acknowledge the village elders and all the local informants for their active participation and sharing of traditional knowledge during the field study. The authors are also thankful to the Director, NERIST and Head, Department of Forestry, NERIST for providing laboratory and working facilities. The first author is grateful to the University Grants Commission, New Delhi, for providing financial assistance in the form of Maulana Azad National Fellowship for Minority student.

\section{Authors' contributions}

PRG designed the objectives and plan of work. TD carried out the field work, analysed the data and wrote the manuscript. PRG helped in data analysis, interpretation of results and finalization of the manuscript.

\section{Conflict of interests}

The authors do not have any conflict of interest.

\section{Supplementary files}

Supplementary Table 1. Diversity and traditional uses of wild edible plants by the Galo tribe of Arunachal Pradesh, India.

\section{References}

1. Beluhan S, Ranogajec A. Chemical composition and nonvolatile components of Croatian wild edible mushrooms. Food Chem. 2010;124:1435-1452. https://doi.org/10.1016/j.foodchem.2010.07.081

2. S Rashid, Ahmad M, Zafar M, Sultana S, Ayub M, Khan MA, et al., Ethnobotanical survey of medicinally important shrubs and trees of Himalayan region of Azad Jammu and Kashmir, Pakistan. J. Ethnopharmacol. 2015;166:340-51. https://doi.org/10.1016/j.jep.2015.03.042

3. Jain AK, Tiwari P. Nutritional value of some traditional edible plants used by tribal communities during emergency with reference to central India. Indian Journal of Traditional Knowledge. 2012;11(1):51-57.

4. Reyes-Garcia V, Menendez-Baceta G, Aceituno-Mata L, AcostaNaranjo R, Calvet-Mir L, Dominguez P, et al. From famine foods to delicatessen: Interpreting trends in the consumption and gathering of wild edible plants through their connection to cultural ecosystem services. Ecol Econ. 2015;120: 303-11. https://doi.org/10.1016/j.ecolecon.2015.11.003

5. Luczaj L, Koncic MZ, Milicevic T, Dolina K, Pandza M. Wild vegetable mixes sold in the markets of Dalmatia (southern Croatia). J Ethnobiol Ethnomed. 2013;9(1):1-12. https://doi.org/10.1186/1746-4269-9-2
6. Rao PK, Hasan SS, Bhellum BL, Manhas RK. Ethnomedicinal plants of Kathua district, J \& K, India. J Ethnopharmacol. 2015;171:12-27. https://doi.org/10.1016/j.jep.2015.05.028

7. Powell B, Kerr RB, Young SL, Johns T. The determinants of dietary diversity and nutrition: ethnonutrition knowledge of local people in the East Usambara Mountains, Tanzania. J Ethnobiol Ethnomed. 2017;13(23):1-12. https://doi.org/10.1186/ s13002-017-0150-2

8. Boedecker J, Termote C, Assogbadjo AE, Van Damme P, Lachat C. Dietary contribution of wild edible plants to women's diets in the buffer zone around the Lama forest, Benin - an underutilized potential. Food Secur. 2014;6(6):833-49. https://doi.org/10.1007/s12571-014-0396-7

9. Uprety Y, Poudel CR, Shrestha KK, Rajbhandary S, Tiwari NN, Shrestha UB, et al. Diversity of use and local knowledge of wild edible plant resources in Nepal. J Ethnobiol Ethnomed. 2012;8(1):16:1-11. https://doi.org/10.1186/1746-4269-8-16

10. Sansanelli S, Tassoni A. Wild food plants traditionally consumed in the area of Bologna (Emilia Romagna region, Italy). J Ethnobiol Ethnomed. 2014; 10(1):69:1-11. https://doi.org/10.1186/1746-4269-10-69

11. Strymets N, Elbakidze M, Ceuterick M, Angelstam P, Axelsson R. From economic survival to recreation: contemporary uses of wild food and medicine in rural Sweden. Ukraine and NW Russia. J Ethnobiol Ethnomed. 2015;11(1):53:1-18 https://doi.org/10.1186/s13002-015-0036-0

12. Ojelel S, Mucunguzi P, Katuura E, Kakudidi EK, Namaganda M, Kalema J. Wild edible plants used by communities in and around selected forest reserves of Teso-Karamoja region, Uganda. J Ethnobiol Ethnomed. 2019;15(1):3:1-14. https://doi.org/10.1186/s13002-018-0278-8

13. Angami A, Gajurel PR, Rethy P, Singh B, Kalita SK. Status and Potential of wild edible plants of Arunachal Pradesh. Indian Journal of Traditional Knowledge. 2006;5(4):541-50.

14. Bisht N, Verma PK, Negi R, Chandra A. An ethnobotanical study of plants used by forest fringe communities of Lwali village (Pauri Garhwal, Uttarakhand). Plant Science Today. 2018;5(2):39-43. https://doi.org/10.14719/pst.2018.5.2.365

15. Mahapatra AK, Panda PC. Wild edible fruit diversity and its significance in the livelihood of indigenous tribals: evidence from eastern India. Food Secur. 2012;4:219-34. https://doi.org/10.1007/s12571-012-0186-z

16. Ray A, Ray R, Sreevidya EA. How many wild edible plants do we eat- Their diversity, use, and implications for sustainable food system: An exploratory analysis in India. Front Sustain Food System. https://doi.org/10.3389/fsufs.2020.00056.

17. Mao AA, Roy DK. Ethnobotanical studies in North East India: a review. Indian ethnobotany: emerging trends. New Delhi: Scientific. 2016;1:99-112.

18. Srivastava RC. Traditional knowledge of Adi tribe of Arunachal Pradesh on plants. Indian Journal of Traditional Knowledge. 2009;8:146-53.

19. Kato D, Gopi GV. Ethnozoology of Galo tribe with special reference to edible insects in Arunachal Pradesh. Indian Journal of Traditional Knowledge. 2009;8(1):81-83.

20. Bora SS, Lahan JP, Borooah M, Sarmah R. Poka- a traditional rice wine of the Galo tribe of Arunachal Pradesh, India. International Journal of Agriculture Sciences. 2012;4(6):268-71. https://doi.org/10.9735/0975-3710.4.6.268-271

21. Ratan O, Mili R, Hui T. Ethnobotany of the Galo community of Arunachal Pradesh, India. Pleione. 2016;10 (2):248-61.

22. Bharali P, Sharma M, Sharma CL, Singh B. Ethnobotanical survey of spices and condiments used by some tribes of Arunachal Pradesh. Journal of Medicinal Plants Studies. 2017;5(1):101-09.

23. Singh AV. Ethnomedicinal studies on the Galo tribe of NariKoyu, East Siang, Arunachal Pradesh. International Journal of Engineering, Science and Mathematics. 2017;6(3):17-24.

24. Kamum G, Kanwal KS, Lod Y. Ethnomedicinal plants used by Galo community of West Siang district, Arunachal Pradesh. International Journal for Research in Applied Science \& 
Engineering Technology.

https://doi.org/10.22214/ijraset.2018.1065

2018;6(1):438-44.

25. Government of India. Census report: Arunachal Pradesh. Ministry of Home Affairs; 2011.

26. Singh TP, Singh S, Roy PS, Rao BSP. Vegetation mapping and characterization in West Siang district of Arunachal Pradesh, India-a satellite remote sensing-based approach. Curr Sci. 2002;83(10):1221-30.

27. Jain SK. Methods and Approaches in Ethnobotany. Society of Ethnobotany, Lucknow, India. 1989.

28. Martin GJ. Ethnobotany: A methods manual. People and Plants Conservation Series. London; Sterling, VA :Earthscan. 2004.

29. Jain SK, Rao RR. A hand book of field and herbarium methods. Oxford and IBH Publishing Company, New Delhi. 1977.

30. Hooker JD. The Flora of British India. Vol. 1-7. London: L. Reeve \& Co. 1875-1897. https://doi.org/10.5962/bhl.title.678

31. Hajra PK, Verma DM, Giri GS, (editor). Materials for the Flora of Arunachal Pradesh. Vol. 1. Kolkata: Botanical Survey of India.

32. Sundriyal M, Sundriyal RC. Wild edible plants of the Sikkim Himalaya: marketing, value addition and implications for management. Econ Bot. 2004;58(2):300-15. https://doi.org/10.1663/0013-0001(2004)058[0300:WEPOTS]2.0.CO;2

33. Chand R, Singh AN, Nirmala C. Ethnoecological survey of underutilised plant diversity of Hamirpur district, Himachal Pradesh, India: an edibility assessment. Environment and Ecology Research. 2017;5 (1):13-29. https://doi.org/10.21746/aps.2016.12.005

34. Tardio J, Pardo-de-Santayana M. Cultural importance indices: a comparative analysis based on the useful wild plants of Southern Cantabria (Northern Spain). Eco Bot. 2008;62(1):2439. https://doi.org/10.1007/s12231-007-9004-5

35. Kayang H. Tribal knowledge on wild edible plants of Meghalaya, Northeast India. Indian Journal of Traditional Knowledge. 2007;6(1):177-81.

36. Lyngdoh N, Piloo N, Gab T, Kumar M, Pandey AK. Wild edible fruit tree resources of Arunachal Pradesh, North East India. Journal of Applied and Natural Science. 2016;8 (2): 883-89. https://doi.org/10.31018/jans.v8i2.891
37. Kar A, Borthakur SK. Wild vegetables sold in local markets of Karbi Anglong, Assam. Indian Journal of Traditional Knowledge. 2007;6:169-72.

38. Pfoze NL, Kumar Y, Sheikh N, Myrboh B. Assessment of local dependency on selected wild edible plants and fruits from Senapati district, Manipur, Northeast India. Ethnobotany $\begin{array}{lll}\text { Research and Applications. 2012;10:357-67. } & \text {. }\end{array}$ https://doi.org/10.17348/era.10.0.357-367

39. FAO and WHO. Rome Declaration on Nutrition. Second international conference on nutrition. Rome, Italy; 2014 Available at: http://www.fao.org/about/meeting/icn2/en/

40. Lockett CT, Calvert CC, Grivetti LE. Energy and micronutrient composition of dietary and medicinal wild plants consumed during drought. Study of rural Fulani, North-eastern Nigeria. Int J Food Sci Nutr. 2000;51:195-208. https://doi.org/10.1080/09637480050029700

41. Agrahar-Murugkar D, Subbulakshmi G. Nutritive values of wild edible fruits, berries, nuts, roots and spices consumed by the Khasi tribes of India. Ecol Food Nutr. 2005;44:207-23. https://doi.org/10.1080/03670240590953025

42. Ahmed J, Rahman IU, AbdAllah EF, Ali N, Shah AH, Ijaz F, et al. Multivariate approaches evaluated in the ethnoecological investigation of Tehsil Oghi, Mansehra, Pakistan. Acta Ecologica $\quad$ Sinica. 2019;39(6):443-50 https://doi.org/10.1016/j.chnaes.2018.11.006

43. Pamei R, Gajurel PR, Singh B. Ethnobotany of medicinal plants used by the Zeliangrong ethnic group of Manipur, northeast India. J Ethnopharmacol. 2019;235:164-82. https://doi.org/10.1016/j.jep.2019.02.009

44. Kahlon LK, Singh R. Traditional knowledge and dynamics of edible plants of primitive tribal group 'Paudi Bhuyan' with changing demography migration patterns in Northern Odisha. Indian Journal of Traditional Knowledge. 2019;18(1):7-15.

45. Srivastava RC. Traditional knowledge of Nyishi (Daffla) tribe of Arunachal Pradesh Indian Journal of Traditional Knowledge. 2010;9(1):26-37.

46. Zaman W, Ahmad M, Zafar M, Amina H, Ullah F, Bahadur S, et al. The quest for some novel antifertility herbals used as male contraceptives in district Shangla, Pakistan. Acta Ecologica Sin$\begin{array}{lll}\text { ica. } & 2020 ; 40(1): 102-12 . & \text { https://doi.org/10.1016/ }\end{array}$ j.chnaes.2019.05.017. 